\title{
Impacts of Migration on the Economy of North-East Nigeria
}

\author{
Omeh Paul Hezekiah, Tobechukwu C. Leo-Nnoli, Abada Ifeanyichukwu Michael*
}

Department of Political Science, University of Nigeria Nsukka, Nsukka, Nigeria

\author{
Email address: \\ ifeanyi.abada@unn.edu.ng (A. I. Michael) \\ ${ }^{*}$ Corresponding author
}

\section{To cite this article:}

Omeh Paul Hezekiah, Tobechukwu C. Leo-Nnoli, Abada Ifeanyichukwu Michael. Impacts of Migration on the Economy of North-East Nigeria. Science Research. Vol. 9, No. 4, 2021, pp. 55-60. doi: 10.11648/j.sr.20210904.13

Received: March 10, 2021; Accepted: March 30, 2021; Published: August 18, 2021

\begin{abstract}
Nigeria as a nation state has shared in the threats caused by globalism. North-Eastern region of Nigeria has in the last couple of years, been witnessing serial outward movement of its population to other neighboring countries. This is perceived as a result of lag on the nature and configuration of Nigerian security engagements which is at the verge of losing war against Boko Haram. More worrisome is the continued decline in the economies of the region due to quantum exit of their labour force to other destinations. The focus of the study is to examine the pull-push variables that had implicated the mass exodus of the labour force, the implications of their exodus on the economy of the region, and the institutional framework designed to revamp their economy. The paper adopted qualitative method, and data were generated through secondary sources and analyzed using content-analysis. The theoretical framework for the study was the Routine Activity Theory (RAT), as propounded by Cohen and Felson, and validated through the empirical works of Clarke and Felson, Felson and Clarke, and Felson. The findings of the study revealed that despite the exerted efforts by government through its institutions, the North-east region has continued to witness mass exodus of people from region, and this has affected the labour force and economic growth of the zone. The paper strongly recommends among others: proactive and total overhauling of the security architecture in the area, as well as establishment of a formidable economic recovery plan/ actions for the zone.
\end{abstract}

Keywords: Boko-Haram, Economy, Human Security, Migration, North-Eastern Nigeria

\section{Introduction}

The primary concern of man from ages has always remained security and need to increase the standard of living couple with the desire to boost the economy. Man's movement from its present state to the intending destination is a factor of decisions taken by him for a purpose. According to United Nations, the movement of people from one place to another (that is, migration) has been a vital response to variables such as environmental challenges, disequilibrium of securitization of lives and property, and social change [1].

Nigeria, like several other nations of the world, is faced with series of challenges one of which is migration. Considered as the most populous country in Africa, and one of the ten most populous in the world, Nigeria witnesses the movement of many of her population (especially the labour force) from various regions/zones of thecountry, out of the country.

The North East geopolitical zone is one of the six zones in Nigeria. It covers one third $\left(280,419 \mathrm{~km}^{2}\right)$ of Nigeria's land area $\left(909,890 \mathrm{Km}^{2}\right)$. The zone is a conglomerate of six states: Adamawa, Bauchi, Borno, Gombe, Taraba, and Yobe. The National Bureau of Statistics has estimated the population of the zone to $23,558,674$ which amounts to $13.5 \%$ of Nigeria's total population $[2,3]$. The region shares international borders with the Republic of Cameroon to the East, Republic of Chad to the North East, and Niger Republic to the North [4]. Nigeria's net migration rate has been negative at $-0.2,-0.2$ and -0.3 per 1,000 persons in 1995, 2008 and 2005 [5].

In the years 2010, 2011, 2013, and 2017, the rate of net migration increased from $0.3,0.38$ and 0.4 per 1,000 persons [6]. These show that the trend of labour force in the North-east zone migrating to other countries within sub-Saharan Africa as emigrants are more than those coming as immigrants. The roles of security agencies in the North East region had been implicated as result of their perceived sabotage, and inabilities in protecting the lives and property of the people. Although the region is blessed with abundant labour force, it is facing serious lapses of lives and property. According to the North East Development Commission, the conflict in the North East zone 
has significantly worsened the general poor socio-economic and infrastructural condition in the area [7]. Every aspect of life has been after: transportation, communication systems, health care, education, banking structures, and so on. Each of these has either been destroyed or seriously damaged. Some other aspects of the effects of the conflicts are decline in the production of food crops and animal husbandry, disruption of economic activities, restriction on social integration and migration.

\section{Conceptual Clarification}

\subsection{Migration}

Migration is the movement of people from one place to another, for the purpose of settling in the new place for some time. It is quite different from mere movement of people from place to place on very short or temporary basis. According to Makinwa, the peculiarity of migration is not limited to present epoch as it occurred during the pre-colonial era [8]. He asserts that group movements, as opposed to individual migration, accounted for the vast bulk of pre-colonial migration.

In North East Nigeria, the level of security lapses have induced individuals, and groups to decide, and to locate to neighbouring countries, or pitch their tents to other regions other than states in North East region. The economy of the zone have been battered as people who were then engaged in one form of economic activity or the other had abandoned these activities and ran for their safety.

\subsection{Urbanization}

Urbanization is the act of moving from the rural areas to the cities [9]. It involves increase in the member of people living in the cities $[10,11]$. It is also a social process whereby acquire material and non-material elements of culture, behaviour patterns and ideas that originate in or distinctive of the city $[12,13]$. The general characteristics of urbanization include; an increase in the number of people engaged in nonagricultural occupations stemming from structural changes and economic growth and increase or decrease of population in urban places $[14,15]$.

It is implicated that the rate of urbanization in the NorthEast has influenced the population to migrate for greener pasture at the cities. This is combined with the wave of security challenges which had cost the lives of the available labour force. The resultant is the fact that the region is fast approaching a surrogate state. The quantities of produce have started diminishing as the needed labour force is nowhere to be found due to intensity of migration and death rate. This has heightened the level of poverty as the economy is at the verge of retreat and crash.

According to Ezeani and Elekwa, urbanization has been on the increase, and the world population has increased from 5767774 billion persons, with $45.7 \%$ living in urban centers while the remaining $35.5 \%$ lived in the rural areas [14]. It is projected that, by the years 2030 , the level of urbanization world-wide would have risen to $61.1 \%$. With an urbanization level of $10.1 \%$ in 1950 , it attained an estimated level of $39.3 \%$ in 1995 and may reach $61.6 \%$ by the year $2025[14,16]$.

\subsection{Human Security}

The security and securitization of lives and property of citizens are some of the fundamental roles of the state. This is why security has occupied a prime position in the constitution of the Federal Republic of Nigeria which maintains that the security and welfare of the people shall be the primary purpose of government [17]. Olabanji and Ese, and Nwanegbo and Odigbo, conceived security as either as a primary responsibility of the state or as the responsibility of non-state actors $[18,19]$. The above conceptualization reflects to the theoretical paradigms of neo-realist and postmodernist extremes. To the post- modernist theorists, security is perceived significantly beyond military weighing of treats and counter treats. They strongly believe that government should be proactive and more concerned with the economic security of individuals than the security of the state because the root cause of insecurity is economic in nature [18].

It is a conventional knowledge that security guarantees the lives and property of citizens. But this is lacking in the North Eastern region of Nigeria where the security personnel are retreating, giving rise to security leakages and free-ride for the insurgentswith terrible implication. Two of the major consequences are migration of labour force out of the region and massive collapse of the economy of the zone. The quantity of produce from the region have declined as needed labour force is migrating to other destinations for safety.

\subsection{Literature Review}

Push- Pull Factors of Migration and Staggered Economy in North East Nigeria.

Occasioned by certain indicators and co-variables, migration in African has taken a paradigm shift as people now, more than ever before, engaged in international migration. People are pulled and prefer to live in urban shanties and slums. According to 2006 United Nations Millennium Development Goals Reports, Sub-Sahara Africa is the world's most rapidly urbanizing region, and almost all of this growth has been in slums, new city residents face overcrowding, inadequate housing, and a lack of water and sanitation. In western Asia, as well, most of the urban growth is occurring in slums. The rapid expansion of urban areas in Southern and Eastern Asia is creating cities of unprecedented size and complexity and new challenges for providing a decent environment for the poor. Northern Africa is the only developing region where the quality of urban life is improving: In this region, the proportion of city dwellers living in slums has decreased by 0.11 percent annually [5].

The above summarizes the nature andtrend of migration in Africa and Nigeria in particular. In the recent times, NorthEast region of Nigeria has come to witness unprecedented outward movement of people especially the labour force. Nwajiuba and Astor et al, have noted that the demographic movement of people from point of residence to destination is a factor of disequilibrium in the socio-economic structure of 
any society $[20,21]$. It constitutes a source of societal pressure and conflicts, environmentaland security challenges. Adejumoke, Ikwuyatum and Olumuyiwa, noted that underutilization of resources, lack of appropriate technology and equipment to work with, incessant power shortage, industrial action and retrenchment are the major sources of migration [22]. On the other hand, some of the effects of migration on the economy of Nigeria and North-East in particular include the fact that the production of food crops and rearing of animal have declined in the region as the needed labouris forced to relocate to other zones or engage in international migration to neighbouring countries like Cameroon, Niger, Chad and Benin Republic.

Table 1. Some socio-economic features of North-East, Nigeria.

\begin{tabular}{lll}
\hline \multirow{2}{*}{ Indicator } & Performance \\
\cline { 2 - 3 } & North-East \\
\hline Absolute poverty - 2016 & $71.10 \%$ \\
Income inequality (Gini Coefficient) - 2016 & $0.5668 \%$ \\
Out of school children (primary school) - 2016 & $44.38 \%$ & $65.9 \%$ \\
Out of school children (JSS) - 2911 & $49.63 \%$ & $0.447 \%$ \\
\% of candidates with 5 credits and above including mathematics and English (WAEC)- 2017 & $8.76 \%$ \\
\hline
\end{tabular}

Source: NEDC, (2017) [7].

The above table reflects the nature and character of the economy of the North East Nigeria as the region has been hit with high level of poverty as high as $69.0 \%$ in 2010 . It depicts the fact that the economy of the North-East is significantly weak to cater for the people. The force of absolute poverty in the region has induced the residents to look for better alternatives to eke out their living. This is traceable, among otherthings, to the volatile conflicts and security challenges bedeviling the region and death rate of people in the zone. The number of deaths as a result of insurgency has been on the increase, and destruction of major economic activities like trade, banking, communication, and transportation, have put the economy in to oblivion and increased the cases of migration out of the region.

Demographic Pressure in North East, Nigeria and its Implications on the Region's Economy.

The North Eastern Nigeria has been naturally endowed with rich soil and vegetation for agricultural purposes. The region has been living peacefully over ages. The communal system of life has also solidified the co-existence of nonindigenes residing in the region. This had helped in boosting the rate of agricultural production, communication, transport, banking system, and the general economy of the zone.

However, no sooner had the economy increased to its optimum level than security lapse started and has induced the population to erratic migration. The result is that socio- economic activities have suffered as people abandoned their economic activities and engaged in one form of migration or the other. The most affected age distribution of those who engages in serial migration is between 18 and 40 years. According to Tukur and Fausat, the socio-economic activities in the North East, especially Borno State since 2009 has seriously witnessed constant decline as people are changing their destination and property subjected to utter destruction by insurgents [23]. Part of the implications is dwindled productivityby the people of the region.

Unfortunately, the inability of the various security outfits in region to quell the crisis, and maintain peace and tranquility, has fueled the rate of migration. The residents are moving out to neighbouring countries like Cameroon, Chad and Niger where they would either temporarily or permanently reside. Even the remaining populace who could not afford to emigrate engage in rural-urban migration. This has subjected the whole of agricultural activities in the rural areas to stoppage. In the rural parts of the region, agricultural production activities havegone very low as the needed manpower is lacking. In the urban areas, economic activities have been greatly halted as people continue to leave the cities to destinations outsidethe North East region. It is on records that greater member of banks and communication facilities have been destroyed, with massive impactson the economy of the region.

Table 2. Socio-Economic Characteristics of North East, 2015.

\begin{tabular}{|c|c|c|c|c|c|}
\hline Characteristics & North East & Adamawa & Borno & Gombe & Yobe \\
\hline Population (million) & $18,971,965$ & $31,168,101$ & $4,151,193$ & 2353879 & $2,321,591$ \\
\hline Ave. household size & 7.3 & 6.0 & 5.3 & 5.9 & 5.5 \\
\hline Literacy rate $\%$ & 28 & 42 & 21 & 34 & 19 \\
\hline \multicolumn{6}{|l|}{ Occupation (\%) } \\
\hline Professional /Managerial & 5.90 & 7.5 & 7.70 & 5.70 & 5.00 \\
\hline Clerical & 0.70 & 1.50 & 1.20 & 0.45 & 0.70 \\
\hline Sales \& services & 34.85 & 34.15 & 31.25 & 39.80 & 39.50 \\
\hline Unskilled manual & 2.30 & $4 . .05$ & 0.40 & 5.85 & 0.60 \\
\hline \multirow[t]{2}{*}{ Agriculture } & 33.8 & 31.95 & 37 & 21.85 & 39.6 \\
\hline & 26.07 & 24.60 & 26.70 & 27.20 & 26.20 \\
\hline
\end{tabular}

Source: Tukur and Fausat, (2015) [23]. 
Table 2 depicts that in the area of agriculture, the percentage of labour force left to produce and contribute to the economy is at minimal for all the five states. Therefore, $38.8 \%$ of $18,971,965$ persons, being the population of the North-East, divided by states that made up the region will give a total of $1,086,755$ persons as the labour force. The number of the available labour forces is not enough to grow nor sustain the economy of the zone.

\subsection{Public Policy, Institutions and North East Economy}

Nigeria has standing rules on immigration and emigration, which are contained therein in the 1999 constitution. The provisions are clearly stated as follows:

The Immigration Act of 1963; laws of the federation of Nigeria 1990, which provides for the conditions of entry, stay and departure of foreign nationals.

The Labour Act; laws of the federation of Nigeria 1990, which governs employment issues in Nigeria. The legislation covers both the situation of Nigerians and non-Nigerian workers.

The International Convention on the Protection of the Rights of All Migrant Workers and their Families.

The Law against Trafficking in Human beings and Migrant Smuggling.

The above legislations cannot be achieved without institutions that would play necessary roles towards the execution of these provisions. However, the management of migration in Nigeria is undertaken by various institutions and bodies. The promulgation through Decree No. 52 of 1989 establishing National Commission for Refugees, charged the commission through section 4 (1) of NCFR Act, 1989, to lay down general guidelines and overall policy matters in relation to refugees and management of internally displaced persons. Likewise, the Ministry of Foreign Affairs plays significant roles in this regard. It oversees consular matters and prepares bilateral agreements among nation states with Nigeria.

The Ministry of Internal Affairs, and the Nigeria Immigration Services, alsocontributes to efficient management of migration into and out of the country. Other institutional actors that help to man the movement of people and goods are: Ministry of Labour and Productivity, Ministry of Justice, National Planning Commission, National Bureau of Statistics, National Population Commission and Nigeria National Volunteer Service. However, despite government's efforts to mitigate migration rate, the North East geopolitical zone has led on the migration trend in Nigeria. This ispartly attributed to the zone's proximity to countries like Chad, Niger and Cameroon. The serial decline in the population of the region has affected the volume of her economy as the zone which was known as one of the hubs of Nigeria's economic hubs is now at the verge of a collapsed economy.

The North East Development Commission (NEDC), and the Presidential Initiative for North East (PINE), are proactive efforts of government to recapitalize the economy for sustainable development. The goal of the North East Development Commission is to normalize the security situation in North East Nigeria by facilitating progressive socio-economic programs for the zone [7]. The objectives of the commission include:

General stabilization of the socio-economic situation in communities affected by insurgency.

Encouraging initiatives that will promote a long-term economic recovery process.

Designing and executing programs of safe return and reintegration of refugees/IDPs to their original homes.

Strengthening community institutions/ self-help structures and promoting their synergy with public ones.

Equipping the youths with basic skills in security and intelligence processes as a step toward neutralization of insurgency cells in the North East [7].

\section{Theoretical Framework of Analysis}

The theoretical framework utilized in this study is Routine Activity Theory (RAT). The theory was propounded by Cohen and Felson (1979). The theory argues that three minimal elements must converge at the same time and in the same place for a predatory crime to occur [24]. These are:

Availability of a suitable target.

Absence of a suitable guardian to prevent the crime from occurring and presence motivated offender [24, 25].

According to Osadebe, a suitable target, which is the first condition for a crime to occur, can be a person, an object, or place [25]. The target of North East Nigeria by insurgents and militia could be linked to its closeness to the borders and its volatile nature. But, it is not enough for the target to be suitable for crime to occur; there must be lapses or absence of a suitable guardian to prevent the crime from occurring. The level of security provided bythe Nigerian Army, police, and other paraphernalia, in the North-East zone is not encouraging. It is equivalentto 'absence of a suitable guardian'. Despite the high volume of security men and women dispatched to the region to maintain peace and order, the level of security is still very poor. A capable guardian must not necessarily be a Police officer or any other government security agent but should be a person whose presence or proximity would discourage crime from occurring [25].

This implies that wanton destruction and crimes would occur if a potential offender thinks that a target is suitable and a capable guardian is absent [25-28]. The above scenario represents the situation in North -East Nigeria. The available of targets, lapses in security structuring, and myriad motivators and insurgents, heightened the trend of crimes and maiming. These have affected the economyand subjected it to serial decline as the needed labour force are fast moving out of the region for their safety. Even the populace at the rural areas are migrating to urban centers, thereby downsizing the volume of agricultural and economic activities of the rural areas. 


\section{Methodology}

The paper utilized documentary method. Data for the study were gathered through secondary sources such as official gazettes, books, journal articles, internet sources, Newspapers and monograph. Data from these sources were analyzed using content-analysis.

\section{Findings}

The fundamental function of government through the established social contract is the protection of the lives and property of the citizens. The state has been charged to maintain both internal and external insurrections. Like every other social organisation, the Nigerian state has been bequeathed with tumult functions which are not entirely different from protection of lives and property of her citizens. The study discovered as findings:

That despite the effort by the government, North-Eastern Nigeria has continued to witness large turnout of people especially the labour force that would have boosted the economy for reason associated with security lapses.

Agricultural activities have been abandoned.

The internally generated revenue accrued to NorthEastern, Nigeria has been reduced.

\section{Conclusion and Recommendations}

The trend of globalization has been noticed and its attendant effects implicating. The high rate of insurgency and lapses in security have led to massive destruction of lives and property in North East Nigeria, resulting to high migration trend, loss of labour force, and weakened economy in the region. This paper explored the pull-push factors that conditioned the movement of people out of North East, and the implications of the movement on the economic activities of the zone. The findings of the study revealed that in as much as government through its security outfits in the North Eastern zone have made some efforts to combat insurgency and related security and economic challenges in the region, the region has continued to witness the movement of large numberof people out of the zone for safety. The paper recommends the following:

There is need to overhaul the security outfits serving in the North East region to weed out 'black legs' among officials sabotaging the effort of the security men.

It is high time government started implementing economic recovery plans for North East Nigeria. The Acts of the parliament establishing the North East Development Commission (NEDC), and Presidential Initiative for North East (PINE), are welcome developmentswhich, if fully implemented facilitate economic recovery.

The integration of community policing, (known also as Neighbourhood Watch) into the security structures in the North East region may help ensure quick identification of perpetrators of crimes and report same to the appropriate quarters.
Government and relevant stakeholders should motivate the remnants who still engage in one form of economic activity or the other in the region, to remain.

\section{References}

[1] United Nations Development Program Reports (2020). Migration Trend in Nigeria.

[2] National Bureau Statistics (2011) Demographic statistics bulletin.

[3] National Bureau Statistics (2015). Demographic statistics bulletin.

[4] Geographic Information System Reports (2018). Retrieved from: https://www.theafricareport.com.

[5] United Nations Development Program Reports (2008). Migration Trend Reports in Nigeria.

[6] United Nations Development Program Reports (2017). Migration Trend Reports in Nigeria.

[7] North East Development Commission (2017). International Migration Reports.

[8] Makinwa, Kofo (1981). Internal Migration and Rural Development in Nigeria: Lessons from Bendel State. Ibadan: Heinemann Educational Books Limited.

[9] Damachi, Godwin Ukandi (1972). Nigeria Modernization: The Colonial Legacy. New York: Third Press.

[10] O'Cornner, Anthony. (1983). The African City. London: Hutchinson and Co. Ltd.

[11] Bloom, Leonard. \& Ottong, Joseph Gabriel (1987). Changing Africa: An Introduction to Sociology. Lagos: Macmillan publishers.

[12] Little, Kenneth. (1974). Urbanization as a Social Process. London: Kegan Paul.

[13] Blackman, Tim (1995). Urban Policy in Practice. London: Routledge.

[14] Ezeani, Onyebuchi. \& Elekwa, N. Nnanta. (2001). Issues in Urbanization and Urban Administration in Nigeria. Enugu: JAMOE Enterprises.

[15] Armstrong Warwick, McGee Terry Gary (1998). Theatres of Accumulation: Studies in Asian and Latin American Urbanization. London, Methuen.

[16] Abiodun, Josephine Olu. (1998). "Environment, Poverty and Sustainable Development in Nigeria Cities," The Nigeria Social Scientists 1 (1) 18.

[17] Federal Republic of Nigeria (1999), Constitution of Federal Republic of Nigeria. Abuja: Government Printer.

[18] Olabanji, Olukayode Ewetan \& Ese, Urhie (2014). "Insecurity and Socio-Economic Development in Nigeria", Journal of Sustainable Development Studies.

[19] Nwanegbo, Chukuemeka Jaja \& Odigbo, J. (2013). Security and national development in Nigeria: The threat of BokoHaram, International Journal of Humanities and Social Science, 3 (4). 
[20] Nwajiuba, Chinedum (2005). International Migration and Livelihood in South Eastern Nigeria: Global Migration Perspective. http://www.gcim.org. Retrieved on 7/4/2018.

[21] Astor Avraham, Akhtar Tasleem, Alexandra María Matallana, Muthuswamy Vasantha, Olowu Folarin A, Tallo Veronica, Lie Reidar K (2005). "Physician Migration: View from Professionals in Columbia, Nigeria, India, Pakistan and Philippine", International Journal of Science and Medicine 61 (12) $187-189$

[22] Adejumoke A. Afolayan; Ikwuyatum, Godwin O. \& Olumuyiwa, Abejide. (2008). Dynamics of International Migration in Nigeria. A Paper Prepared as Part of the African Perspectives on Human Mobility Programmes, Department of Geography, University of Ibadan, Nigeria.

[23] Tukur, Mohammed Danladi \& Fausat, Ahmed Funmilola (2015). "The effect of Insurgency on Borno State Economy, (2006-2014)", Journal of Economics and Sustainable Development 6 (16) 94-102.
[24] Cohen, Lawrence. E. \& Felson, Marcus. (1979). "Social Change and Crime Trends. A Routine Activity Approach", American Sociological Review 44 (1) 588-608.

[25] Osadebe, Nmabuike. O. (2014). "Some Sociological Theories and their Application in Research" in Ikeanyibe, M. O. \& Mbah, P. O. (ed) An Anthology of Theories for Social Research. Nsukka: University of Nigeria Press Ltd.

[26] Clark, Ronald. V. \& Felson, Marcus. (1995). "Routine Activity and Rational Choice," Journal of Advance Criminology Theory 5 (2), 11-13.

[27] Felson, Marcus. \& Clark, Ronald. V. (1998). “Opportunity Makes the Thief”, Police Research Series 9 (8), 11-13.

[28] Felson, Marcus. (1998). Crime and Everyday Life. Oaks: Pine Forge Press. 